\title{
Effect of Astaxanthin Supplementation on Blood Plasma Leptin and IgG Profiles in Pre and Postpartum Murrah (Bubalus bubalis) Buffaloes during Different Seasons
}

\author{
Lakshmi Priyadarshini* and Anjali Aggarwal
}

Animal Physiology Division, ICAR-National Dairy Research Institute, Karnal, 132001, Haryana, India

*Corresponding author

\begin{abstract}
A B S T R A C T
The study was conducted to evaluate the effect of astaxanthin supplementation on blood plasma leptin and IgG profiles in pre and postpartum Murrah buffaloes during different

\begin{tabular}{|c|}
\hline Keywords \\
\hline $\begin{array}{l}\text { Astaxanthin, } \mathrm{IgG} \text {, } \\
\text { Leptin, Summer, } \\
\text { Winter }\end{array}$ \\
\hline Article Info \\
\hline $\begin{array}{l}\text { Accepted: } \\
\text { 15 May } 2018 \\
\text { Available Online: } \\
\text { 10 June } 2018\end{array}$ \\
\hline
\end{tabular}
seasons. For this, thirty two pregnant dry Murrah buffaloes were selected from Livestock Research Centre at National Dairy Research Institute, Karnal. The buffaloes were divided into four groups consisting of eight Murrah buffaloes in each control and supplemented groups of buffaloes during summer (THI $=83.2 ; \mathrm{RH}=72.78 \%$ ) and winter season (THI=58.0; RH=55.20\%), respectively. All groups were fed according to nutrient requirement of buffaloes (ICAR, 2013). The treatment group was supplemented with astaxanthin @ $0.25 \mathrm{mg} / \mathrm{kg}$ body weight/animal/day during the period 30 days prior to expected date of calving and upto 30 days postpartum. Blood samples were collected on $30,-15,-7,0,+7,+15,+30,+45$ and +60 days with respect to calving where day ' 0 ' represents the day of calving. The plasma leptin and IgG levels of treatment group differed significantly $(\mathrm{P}<0.05)$ as compared to control group during both seasons. Plasma leptin and $\operatorname{IgG}$ was higher $(\mathrm{P}<0.05)$ in winter as compared to summer season. The increase of heat load during summer season presented as THI on buffalo decreases leptin and total IgG level in plasma.
\end{abstract}

\section{Introduction}

Transition period in dairy buffaloes presents a risk interval for metabolic disorders. An increased capability of milk production is associated with the changes of metabolic and energy homeostasis (Butler, 2000; Lucy, 2003). An increase in energy requirements during late pregnancy and early lactation makes dairy cows highly susceptible to negative energy balance (NEB) which commonly occurs in the transition period. The metabolic adaptation to NEB requires interactions of metabolic fuels and its failure may occur in various tissues like the liver, adipose tissue and others (Herdt, 2000). Intensified processes of NEFA oxidation proceeded in the liver, result in the increased production of reactive oxygen species (ROS) and oxidative stress development. Thus, metabolic profiles as well as antioxidative/ prooxidative status is a useful tool for 
monitoring health and reproduction status in buffaloes during the transition period. Astaxanthin is a lipophilic, pinkish-orange carotenoid (3,3'-dihydroxy- $\beta, \beta$-carotene- 4,4 'dione) found in algae, seafood (crustacean shells, crab, shrimps, fish) by Qin et al., (2008) and various plants, giving them their exclusive colored aspect (Zhao et al., 2011).

The main source of astaxanthin is the microalga Haematococcus pluvialis, which contains maximum concentrations (Boussiba et al., 2000). Astaxanthin is also used as a dietary additive in the USA, Japan, South Korea and Sweden (Choi et al., 2011). Like other carotenoid, astaxanthin manifests high protective antioxidant (Aoi et al., 2008; Derosa et al., 2014) and anticancer (Kavitha et al., 2013; Kowshik et al., 2014; Palazza et al., 2015) properties which decreases oxidative stress and inflammation (Choi et al., 2011; Wolf et al., 2010; Sahebkar et al., 2015), reduces rethrombosis after thrombolysis (Lauver, 2008) and is efficient in ischemiareperfusion (Gross and Lockwood, 2004), arterial hypertension (Hussein et al., 2005; Hussein et al., 2006) and dyslipidemia (Hussein et al., 2005; Banach et al., 2014).

Leptin is a protein hormone secreted by adipose tissues and acts on hypothalamus to regulate feed intake (Hossner, 1998) and energy balance (Soliman et al., 2002). Leptin is also associated with other biological processes such as reproduction, hematopoiesis, immune response and bone formation (Olusi et al., 2003). It has been reviewed that an increase in the circulating leptin concentration is involved in regulation of metabolic rate, macrophage function and induction of immune cell proliferation or differentiation. Moreover, leptin concentration in plasma has been a direct reflection of the amount of body fat and reproductive function through its effect on nutritional status (Agrawal et al., 2008).
IgG includes circulating antibodies which act against diseases antigens. It is formed by plasma cells found within lymphatic system of animal body (Choudhary et al., 2006). Shearer and Beede, (1990) reported that serum IgG concentrations were altered in peripheral serum of Holstein calves in subtropical climate.

\section{Materials and Methods}

\section{Location of the farm}

The present study was conducted at the Cattle Yard of National Dairy Research Institute (NDRI), Karnal (Haryana) which is situated on an altitude of 250 meter above mean sea level at latitude of $29^{\circ} 42^{\prime} \mathrm{N}$ and longitude of $79^{0} 54$ 'E.

The maximum ambient temperature during summer goes up to $45^{\circ} \mathrm{C}$ and minimum temperature in winter comes down to $0^{\circ} \mathrm{C}$ with a diurnal variation of $15-20^{\circ} \mathrm{C}$.

\section{Experimental animals}

Thirty two pregnant Murrah buffaloes (zero to third parity) were selected 16 in summer (April-June) and 16 in winter season (December-February) from the livestock herd of National Dairy Research Institute, Karnal. From these 16 animals were further randomly divided equally ( 8 each) into two groups i.e. control and supplemented group of buffaloes. The duration of experiment was from 30 days before expected date of calving to 60 days after parturition.

\section{Ethics Approval}

Experiment was approved and conducted under the established standard of the institutional Animal Ethics Committee (IAEC), constituted as per the article number 13 of the Committee for the Purpose of 
Control and Supervision of Experiments on Animals (CPCSEA) rules laid down by the Government of India.

\section{Feeding of experimental animals}

All the animals were fed as per ICAR feeding standard. The rations consisted of green fodder and concentrate mixture. Control groups of buffaloes remained as without supplementation of astaxanthin during summer and winter seasons, respectively. Treatment groups of buffaloes were supplemented with astaxanthin during summer and winter seasons, respectively. The astaxanthin as powder form was fed @ 0.25 $\mathrm{mg} / \mathrm{kg}$ body weight/day mixing with concentrate mixture, from 30 days before parturition till 30 days after parturition.

\section{Collection of blood samples}

Blood samples (7-9 ml) were collected in sterile Potassium-EDTA coated vacutainer tubes (BD-PlymouthPL6 7BP, UK) from jugular vein puncture, posing minimum disturbance to animal, on the days $-30,-15,-7$, $0,7,15,30,45$ and 60 with respect to day of parturition. Day ' 0 ' represented the day of calving. Samples were brought to the laboratory in chilled ice boxes soon after collection and centrifuged at $1200 \mathrm{xg}$ at $4^{\circ} \mathrm{C}$ for 20 minutes to separate the plasma from packed erythrocytes. The plasma was decanted in another numbered, clean, dried plastic eppendrof vials. The plasma samples were analyzed for leptin and IgG.

Leptin was determined in plasma using "Bovine Leptin Enzyme-Linked Immunosorbent Assay Kit" (Catalog No. E0014Bo) supplied by Bioassay Technology Laboratory. Immunoglobulin $\mathrm{G}$ was determined in plasma using "Bovine Immunoglobulin $\mathrm{G}$ Enzyme-Linked Immunosorbent Assay Kit" (Catalog No.
E0010Bo) supplied by Bioassay Technology Laboratory.

\section{Statistical analysis}

The data analysis was carried out by SAS software, Version (9.3) of the SAS system for Window, Copyright(C) (2011) SAS Institute Inc., Cary, NC, USA and Prism 5 software. Three way ANOVA and Tukey's multiple comparison tests were used.

\section{Results and Discussion}

The plasma levels of leptin in periparturient Murrah buffaloes during summer and winter seasons are presented in Fig. 1 and Fig. 2. The mean plasma level of leptin during summer season were $5.94 \pm 0.29$ vs. $5.98 \pm 0.30$, $2.25 \pm 0.19$ vs. $3.88 \pm 0.17$ and $3.07 \pm 0.16$ vs. $4.44 \pm 0.17$, respectively of control and treatment groups of buffaloes on $-30,0,+60$ days. The levels significantly decreased by $62.12 \%$ and $35.11 \%$ in control and treatment groups of buffaloes on 0 day. The plasma leptin level of treatment group differed significantly $(\mathrm{P}<0.05)$ as compared to control group on day 7 before calving upto day 60 after calving. The mean plasma level of leptin during winter season were $3.93 \pm 0.16$ vs. $3.94 \pm 0.17, \quad 2.36 \pm 0.23$ vs. $3.01 \pm 0.22$ and $2.99 \pm 0.19$ vs. $3.52 \pm 0.12 \mathrm{ng} / \mathrm{ml}$, respectively of control and treatment groups of buffaloes on $30,0,+60$ days. The levels significantly decreased by $40 \%$ and $23.60 \%$ in control and treatment groups of buffaloes on 0 day. The plasma leptin level of treatment group differed significantly as compared to control group on day $15^{\text {th }}$ before calving and from day 7 to 45 after calving. Plasma leptin was higher $(\mathrm{P}<0.05)$ in winter as compared to winter season. The analysis of variance of data has been provided in Table 1. leptin revealed a significant difference between season $(\mathrm{p}<0.01)$, day $(\mathrm{p}<0.01)$, animal $(\mathrm{p}<0.01)$, season*day $(\mathrm{p}<0.01)$. 
The plasma levels of $\operatorname{IgG}$ in control and treatment groups of periparturient Murrah buffaloes during summer and winter conditions are presented in Fig. 3 and Fig. 4. The mean plasma IgG level in control and treatment groups of Murrah buffaloes were $57.21 \pm 0.38$ vs. $57.08 \pm 0.28,40.68 \pm 0.27$ vs. $42.93 \pm 0.29$ and $50.23 \pm 0.18$ vs. $54.58 \pm 0.36$ $\mu \mathrm{g} / \mathrm{ml}$, on $-30,0$ and +60 days, respectively during summer season and $58.34 \pm 0.46$ vs. $58.87 \pm 0.36,48.01 \pm 0.40$ vs. $53.59 \pm 0.22$ and $54.11 \pm 0.41 \quad$ vs. $57.02 \pm 0.23 \mu \mathrm{g} / \mathrm{ml}$ during winter season, respectively.

The plasma IgG level of treatment group was significantly $(\mathrm{P}<0.05)$ higher as compared to control group on day 15 before calving, on day of calving and postpartum period. The plasma IgG level of treatment group was significantly $(\mathrm{P}<0.05)$ higher as compared to control group on day 7 before calving, on day of calving and on days 15,30 and 60 after calving. Plasma IgG level was higher $(\mathrm{P}<0.05)$ in winter than in summer season.

The low concentration of leptin during the month of August when THI was more is in agreement with the results of Mann et al., (2000) who reported that leptin reached a nadir in late winter (August to September), while being at its peak in late winter (January to March).

This is because of the critical role of leptin in regulating energy metabolism (Block et al., 2003). Astaxanthin treated groups had higher leptin level. It may be due to the fact that astaxanthin is an antioxidant which reduces the oxidative damage of source of leptin i.e. white adipose tissues. During parturition, there was reduction in the level of circulating leptin due to onset of energy deficit. Leptin concentration during pregnancy was higher which declined rapidly towards calving (Maurya, 2011). In the present study also we found the plasma leptin concentration was significantly lower on the day of parturition in both the seasons. The leptin concentration depressed during postpartum period despite a gradual increase in energy balance (Block et al., 2001). Energy conservation increased by hypoleptinemia in early postpartum period and by promoting enhanced metabolic efficiency (Leury et al., 2003). Leptin has role in feed intake and energy disposition as well as help in the co-ordination of metabolism during the pre-partum to postpartum period. Transition from pregnancy to lactation in dairy cows was associated with a decreased in the plasma leptin level (Thorn et al., 2008; Maurya, 2011). In our result, plasma leptin level was higher $(\mathrm{p}<0.05)$ in winter season as compared to summer season.

Decline in plasma leptin around parturition might be due to decrease in adiposities and insulin concentration. Vaidya et al., (2012) found leptin level in high and low yielding Sahiwal cow $(5.81 \pm 0.14$ vs. $5.54 \pm 0.10)$ in summer and $(6.12 \pm 0.10$ vs. $5.90 \pm 0.21 \mathrm{ng} / \mathrm{ml})$ in winter season on $45^{\text {th }}$ day of prepartum, however, $(5.98 \pm 0.07$ vs. $5.98 \pm 0.31)$ in summer and $(6.26 \pm 0.20$ vs. $5.79 \pm 0.13)$ in winter in Karan Fries cows, respectively. Hafez (2013) reported that the increase of heat load during August to September presented as THI on lactating buffalo decreases their leptin hormone level in blood plasma.

Aarif (2014) showed that plasma leptin $(\mathrm{ng} / \mathrm{ml})$ level were significantly $(\mathrm{P}<0.05)$ different $(4.53 \pm 0.09$ vs. $3.13 \pm 0.06)$ in Murrah buffaloes without provision of cooling and managed under cooling, respectively, on day of calving during summer season.

The mean plasma level of leptin $(\mathrm{ng} / \mathrm{ml})$ in Sahiwal cows during thermoneutral to summer season on $-15,0,+15$ days of parturition were $6.35 \pm 0.21$ vs. $6.60 \pm 0.12, \quad 5.40 \pm 0.11$ vs. $6.46 \pm 0.18$ and $5.56 \pm 0.08$ vs. $6.78 \pm 0.06 \mathrm{ng} / \mathrm{ml}$, respectively (Somal and Aggarwal, 2014). 
Table.1 ANOVA Table for leptin and IgG

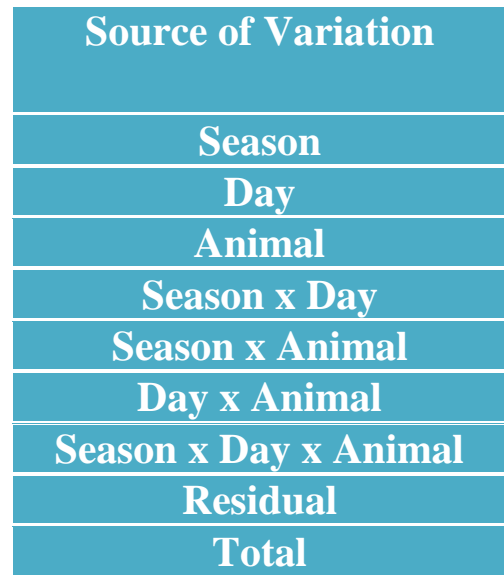

\begin{tabular}{|c|c|c|}
\hline \multirow{2}{*}{ df } & \multicolumn{2}{|c|}{ Mean sum of squre } \\
\hline & Leptin & $\operatorname{IgG}$ \\
\hline 1 & $48.81^{* *}$ & $1220.14^{* *}$ \\
\hline 8 & $13.39^{* *}$ & $437.51^{* *}$ \\
\hline 7 & $7.62^{* *}$ & 1.63 \\
\hline 8 & $4.61^{* *}$ & $40.60^{* *}$ \\
\hline 7 & 0.46 & 1.42 \\
\hline 56 & 0.12 & 1.08 \\
\hline 56 & 0.10 & 0.83 \\
\hline 144 & 0.67 & 4.68 \\
\hline 287 & 1.25 & 20.37 \\
\hline
\end{tabular}

Where $* * p<0.01$

Fig.1 Changes in plasma leptin $(\mathrm{ng} / \mathrm{ml})$ of control and treatment groups of buffaloes during pre and post-partum period in summer season

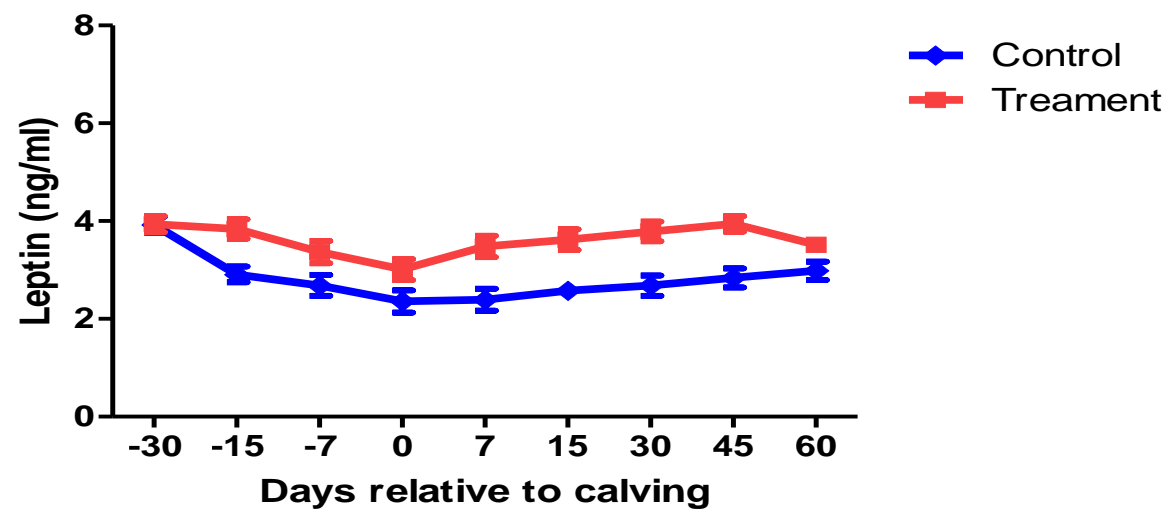

Fig.2 Changes in plasma leptin $(\mathrm{ng} / \mathrm{ml})$ of control and treatment groups of buffaloes during pre and post-partum period in winter season

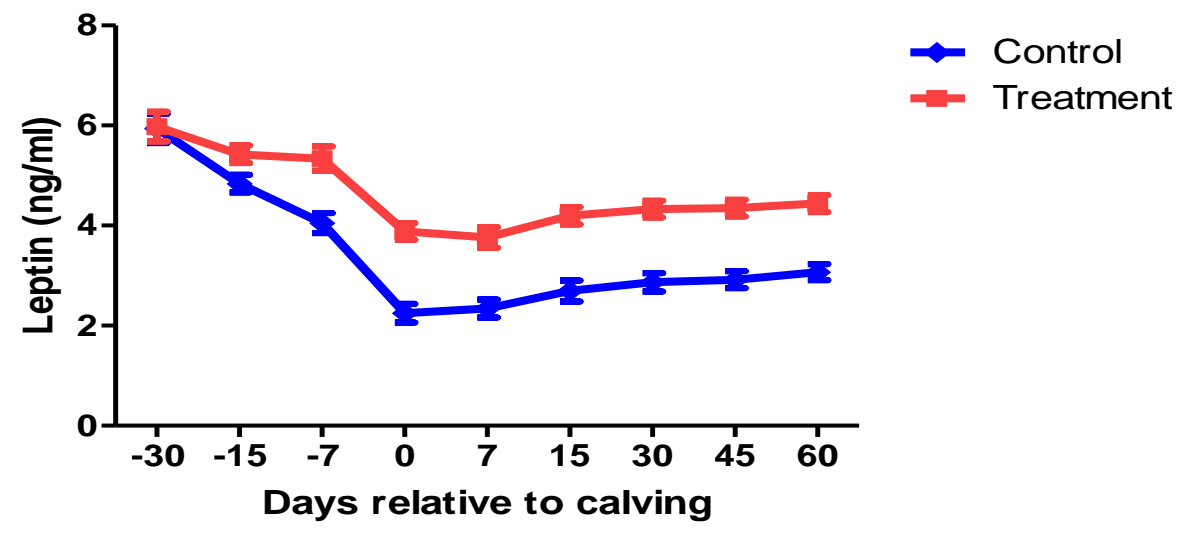


Fig.3 Changes in plasma IgG $(\mu \mathrm{g} / \mathrm{ml})$ of control and treatment groups of buffaloes during pre and post-partum period in summer season

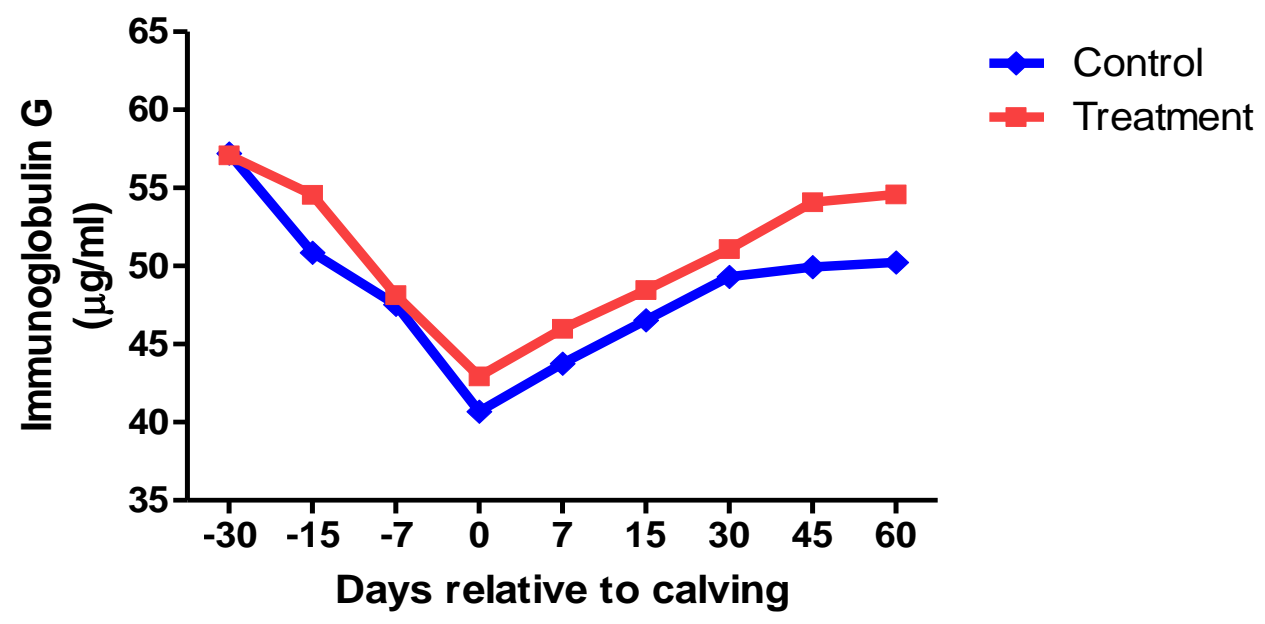

Fig.4 Changes in plasma $\operatorname{IgG}(\mu \mathrm{g} / \mathrm{ml})$ of control and treatment groups of buffaloes during pre and post-partum period in winter season

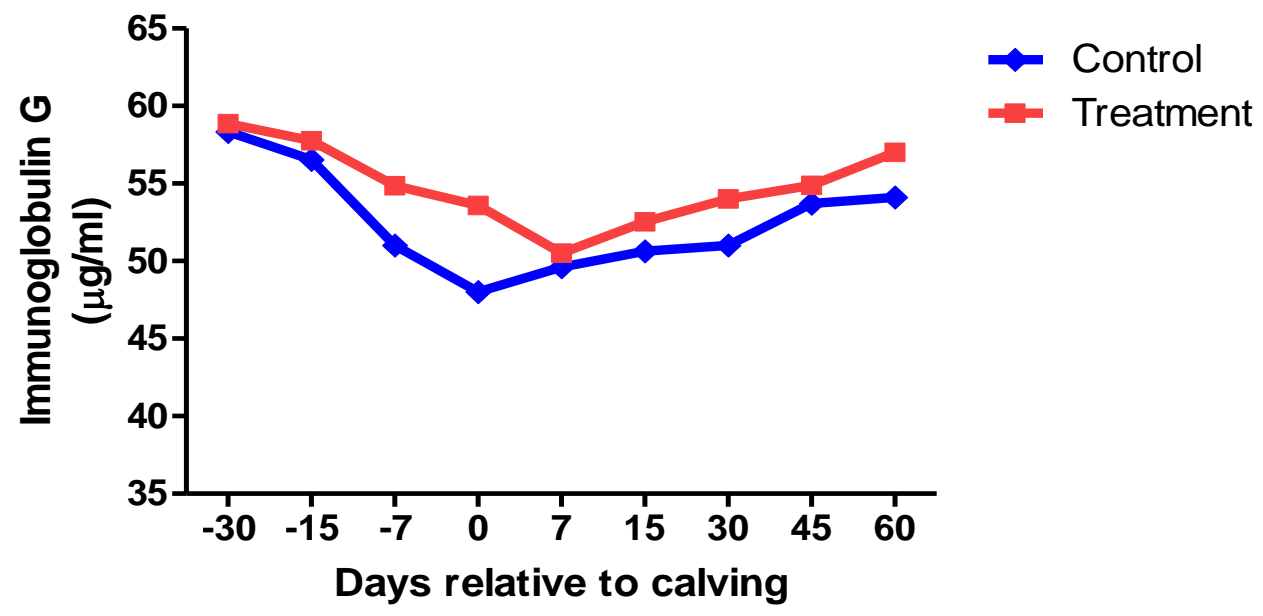

Park et al., (2011) found the IgG levels $(\mathrm{mg} / \mathrm{ml})$ were $13.4 \pm 1.6,13.2 \pm 1.8,15.3 \pm 2.5$ and $16.3 \pm 1.1$ in $1^{\text {st }}$ week, $12.3 \pm 2.1,14.6 \pm 2.3$, $13.9 \pm 0.9$ and $18.7 \pm 2.8$ in $8^{\text {th }}$ week and $14.5 \pm 2.6,15.6 \pm 2.2,23.6 \pm 4.5$ and $18.9 \pm 2.7$ in $12^{\text {th }}$ week of experimental period after $0,1,5$ and $10 \mathrm{mg} / \mathrm{d}$ astaxanthin supplementation, respectively, in female domestic shorthair cats. During August to September when temperature and humidity were high total $\mathrm{IgG}$ level in blood plasma in lactating buffalo decreased (Hafez, 2013).

IgG concentration was found to be significant $(\mathrm{P}<0.05)$ higher in treatment groups than that of control during both summer and winter seasons. Tengerdy (1980) showed stimulatory effect of supplementation of vitamin $E$ on serum antibody synthesis, mainly IgG. Mili et al., (2015) reported a significant $(\mathrm{P}<0.05)$ rise 
in plasma $\operatorname{IgG}$ level by supplementation of vitamin $\mathrm{E}$ to periparturient buffaloes $(24.68 \pm 1.06$ vs $23.45 \pm 0.68 \mathrm{mg} / \mathrm{ml})$. The changes of $\operatorname{IgG}$ were also significant between different days in both the groups of buffaloes during summer and winter seasons. Minimum value of $\operatorname{IgG}$ was observed on day of caving which further increased in post-partum period. This is supported by Herr et al., (2011) and Mili et al., (2015) who showed IgG level $27.73 \pm 1.60 \mathrm{mg} / \mathrm{ml} 56$ days before calving to $17.42 \pm 1.54 \mathrm{mg} / \mathrm{ml}$ on the day of calving in control and $28.07 \pm 1.72 \mathrm{mg} / \mathrm{ml}$ to $18.96 \pm 1.72 \mathrm{mg} / \mathrm{ml}$ in vitamin E supplemented group. El-Desouky (2014) reported that the serum IgG level increased from the $30^{\text {th }}$ day before to the $15^{\text {th }}$ day after parturition in the celmanax (an immune-stimulant prebiotic drug) supplemented group than that of control group in dairy cow. Due to presence of high amount of polyunsaturated fatty acids (PUFA) in cell membrane of immune cells, these are sensitive to oxidative damage. IgG level increased by supplementation of astaxanthin; it could neutralize reactive oxygen species and immune cells protected by lipid peroxidation. In our result, plasma IgG level was significantly higher in winter as compared to summer season. In the present study it was found that the plasma level of $\mathrm{IgG}$ declined on the day of calving and then again increased post calving. Our findings were similar to previously reported findings that the immunoglobulin levels decrease towards calving (Chandra, 2009). Maurya, (2011) also reported that lymphocyte proliferation index was reduced towards parturition and then again increased after calving. Negative energy, protein, and/or mineral balance associated with the onset of lactation may be partially responsible for the immunosuppression observed in periparturient dairy cattle (Kimura et al., 1999). This has consequences for both the innate and adaptive immune responses. Neutrophil and lymphocyte function is diminished in the periparturient period, especially in the dairy cow (Kehrli et al., 1989).

The plasma level of leptin was lowest on the day of calving in control and supplemented groups of buffaloes during summer season with respect to 30 days pre and 60 days post calving. The plasma level of $\operatorname{IgG}$ decreased on the day of calving in control and supplemented groups of buffaloes during summer season with respect to 30 days pre and 60 days post calving. Plasma leptin and $\mathrm{IgG}$ level was significantly higher in winter as compared to summer season. The increase of heat load during summer season presented as THI on buffalo decreases leptin and total IgG level in blood plasma.

\section{Acknowledgments}

This study was financially supported by National Initiative on Climate Resilient Agriculture, Indian Council of Agricultural Research (NICRA-ICAR), New Delhi (Grant no. 2049/3033). The authors gratefully acknowledge Director, ICAR-National Dairy Research Institute, Karnal for providing necessary facilities to conduct this study.

\section{References}

Aggarwal, R., Rout, P.K. and Singh, A.K. 2008. Leptin a biomolecule for enhancing livestock productivity. Indian J. Biotechnol., 8: 169-176.

Aoi, W., Naito, Y., Takanami, Y., Ishii, T., Kawai, Y., Akagiri, S., Kato, Y., Osawa, T. and Yoshikawa, T. 2008. Astaxanthin improves muscle lipid metabolism in exercise via inhibitory effect of oxidative CPTI modification. Biochem.Biophys. Res. Commun. 366: 892-897.

Banach, M., Serban, C., Aronow, W.S., Rvsz, J., Dragan, S., Lerma, E.V., Apetrii, M. 
and Covic, A. 2014. Lipid, blood pressure and kidney update. Int. Urol. Nephrol. 46: 947-61.

Block, S.S., Butler, W.R., Ehrhardt, R.A., Bell, A.W., Van Amburgh, M.E. and Boisclair, Y.R. 2001. Decreased concentration of plasma leptin in periparturient dairy cows caused by negative energy balance. Int. J. Endocrinol. 171: 339-348.

Block, S.S., Smith, J.M., Ehrhardt, R.A., Diaz, M.C., Rhoads, R.P., Van Amburgh, M.E. and Boisclair, Y.R. 2003. Nutritional and developmental regulation of plasma leptin in dairy cattle.J. Dairy Sci. 86: 3206-3214.

Boussiba, S., Cohen, Z., Richmond, A. and Vonshak, A. 2000.Procedure for largescale production of astaxanthin from Haematococcus. Google Patents.

Butler, W.R. 2000.Nutritional interactions with reproductive performance in dairy cattle.Anim. Reprod. Sci.60: 446-457.

Choi, H.D., Kang, H.E., Yang, S.H., Lee, M.G. and Shin, W.G. 2011. Pharmacokinetics and firstpassetabolism of astaxanthin inrats. $B r$. J. Nutrition. 105: 220-227.

Choudhary, V., Kumar, P., Saxena, V.K., Bhattacharya, T.K., Bhushan, B., Sharma, A. and Ahmed, K.A. 2006.Effect of leptin and IGFBP-3 gene polymorphisms on serum IgG level of cattle calves.Asian-Aust. J. Anim. Sci. 19(8): 1095-1099.

Derosa, G., Limas, C.P., Macías, P.C., Estrella, A. and Maffioli, P. 2014. Dietary and nutraceutical approach to type 2 diabetes. Arch. Med. Sci. 10: 336-344.

Gross, G.J. and Lockwood, S.F. 2004. Cardioprotection and myocardial salvage by a disodium disuccinate astaxanthin derivative. Life Sci. 75: 215224.

Herdt, T.H. 2000. Variability characteristics and test selection in herd-level nutritional and metabolic profile testing. Vet. Clin.North Am. Food Anim. Pract. 16: 387-403.

Hossner, K. L. 1998. Cellular, molecular and physiological aspects of leptin: Potential application in animal production. Can. J. Anim. Sci. 78: 463-472.

Hussein, G., Nakamura, M., Zhao, Q., Iguchi, T., Goto, H., Sankawa, U.and Watanabe, H. 2005. Antihypertensive and neuroprotective effects of astaxanthin in experimental animals. Biol. Pharm. Bull. 28: 47-52.

Hussein, G., Sankawa, U., Goto, H., Matsumoto, K. and Watanabe, H. 2006. Astaxanthin, a carotenoid with potential in human health and nutrition.J. Nat. Prod. 69: 443-449.

Kavitha, K., Kowshik, J., Kishore, T.K., Baba, A.B. and Nagini, S. 2013. Astaxanthin inhibits NF-kappaB and Wnt/beta-catenin signaling pathways via inactivation of Erk/MAPK and $\mathrm{PI} 3 \mathrm{~K} / \mathrm{Akt}$ to induce intrinsic apoptosis in a hamster model oforal cancer. Biochem. Biophys. Acta. 1830: 44334444.

Kowshik, J., Baba, A.B., Giri, H., Deepak Reddy, G., Dixit, M. and Nagini, S. 2014. Astaxanthin inhibitsJAK/STAT-3 signaling to abrogate cell proliferation, invasion and angiogenesis in a hamster model of oral cancer. PLoS One. 9(10):109-114.

Lauver, D.A., Driscoll, E.M. and Lucchesi, B.R. 2008.2 Disodium disuccinateastaxanthin prevents carotid artery rethrombosisand ex vivo platelet activation. Pharmacology.82: 67-73.

Leury, B.J., Baumgard, L.H., Block, S.S., Segoale, N., Ehrhardt, R.A., Rhoads, R.P., Bauman, D.E., Bell, A.W. and Boisclair, Y.R. 2003.Effect of insulin and growth hormone on plasma leptin in periparturient dairy cows.Am. J. 
Physiol. Regul. Integr. Comp. Physiol.285: 1107-1115.

Lucy, M.C. 2003. Mechanisms linking nutrition and reproduction in postpartum cows. Reproduct. Supply. 61: 415-427.

Mann, D.R., Akinbami, M.A., Gould, K.G. and Castracane, V.D. 2000. A longitudinal study of leptin during development in the male rhesus monkey: the effect of body composition and season on circulating leptin levels.Biol. Reprod.62: 285-291.

Maurya, P. 2011. Leptin level in relation to immunity, energy metabolites and cellular adoptations during dry period and early lactation in crossbred cows. M.V.Sc. Thesis, NDRI (deemed University), Karnal (Haryana), India.

Olusi, S., Al-Awadhi, A., Abiaka, C., Abraham, M., George, S. 2003. Serum copper levels and not zinc are positively associated with serum leptin concentrations in the healthy adult population. Biol. Trace. Elem. Res.91: 137-144.

Palazzo, L., Thomas, B., Jemth, A.S., Coldy, T., Leidecker, O., Feijs, K.L.H., Zaja, R., Loseva, O., Puigvert, J. C., Matic, I., Helleday, T. and Ahel, I. 2015.Processing of protein ADPribosylation by nudix hydrolases. Biochem. J. 468(2): 293-301.

Qin, S., Liu, G.X. and Hu, Z.Y. 2008. The accumulation and metabolism of astaxanthin in scenedesmusobliquus. Process Biochem. 43: 795-802.
Sahebkar, A., Serban, C., Ursoniu, S. and Banach, M. 2015. Effect of curcuminoids on oxidative stress: a systematic review and meta-analysis of randomized controlled trials. J. Funct. Foods. DOI: 10.1016/j.jff.2015.01.005.

Shearer, J.K. and Beede, D.K. 1990.Thermoregulation and physiological responses of dairy cattle in hot weather.Agri. Pract. 11: 5-17.

Soliman, M., Ishioka, K., Yoshida, R., Komabayashi, K., Hatai, H., Matsui, Y., Hirai, T., Katagiri, S., Takahashi, Y., Kawakita, Y., Abe, H., Kitamura, H., Kimura, K. and Saito, M. 2002. Serum leptin levels during the periparturient period in cows. J. Vet. Med. Sci.64: 1053-1056.

Thorn, S.R., Ehrhardt, R.A., Butler, W.R., Quirk, S.M. and Boisclair, Y.R. 2008. Insulin regulates hepatic leptin receptor expression in early lactating dairy cows. Am. J. Physiol. Regul. Integr. Comp. Physiol.295: 1455-1462.

Wolf, A.M., Asoh, S., Hiranuma, H., Ohsawa, I., Iio, K., Satou, A., Ishikura, M. and Ohta, S. 2010. Astaxanthin protects mitochondrial redox state and functional integrity against oxidative stress. $J$. Nutr. Biochem. 21(5): 381-389.

Zhao, Z.W., Cai, W., Lin Y.L., Lin, Q.F., Jiang, Q., Lin, Z. and Chen, L.L. 2011. Ameliorative effect of astaxanthin on endothelial dysfunction in streptozotocin-induced diabetes in male rats. Arzneimittelforschung. 61: 239246.

\section{How to cite this article:}

Lakshmi Priyadarshini and Anjali Aggarwal. 2018. Effect of Astaxanthin Supplementation on Blood Plasma Leptin and IgG Profiles in Pre and Postpartum Murrah (Bubalus bubalis) Buffaloes during Different Seasons. Int.J.Curr.Microbiol.App.Sci. 7(06): 1303-1311. doi: https://doi.org/10.20546/ijcmas.2018.706.153 